\title{
China and international financial reform
}

Wing Thye Woo ${ }^{1}$

\section{Unhappiness with the international economic architecture all round}

The founding principle of economics is that the division of labour increases output. The growth experience of China in the past three decades confirms the validity of this basic insight by Adam Smith on the productivity effects of task specialisation. Thanks to China's rapidly increasing labour-intensive manufactured exports to the rest of the world, China has industrialised at a record pace and hence has also reduced rural poverty at a record pace through the reduction of surplus agricultural labour. China is now the world's largest exporter of textiles, shoes and toys, and also the world's largest recipient of foreign direct investment (FDI). China has clearly been a big beneficiary of the post-World War II global economic system that has promoted economic globalisation.

Economic globalisation has been driven by two processes: the deregulation of international trade; and the opening of national capital markets to achieve an integrated global financial system. The pillar of the international economic architecture that had fundamental responsibility for encouraging trade deregulation was first the General Agreement on Tariffs and Trade (GATT) and is now the World Trade Organisation (WTO). The pillar that has encouraged the lifting of obstacles to crosscountry capital movements is the International Monetary Fund (IMF), beginning in the 1980s. ${ }^{2}$ The increase in economic globalisation has made the currency of the United States, the US dollar, the keystone of the international economic architecture because the US dollar is the currency most commonly used to denominate cross-country transactions in goods, services and financial assets. ${ }^{3}$

China is of course not the only country that has performed well under this postwar international economic architecture. Economic globalisation 
also accelerated the development of other Asian countries such as Malaysia, South Korea, Taiwan and Thailand. India, too, attained a higher rate of economic growth after it started steady opening of its economy to international trade and investment from 1991 onwards. In fact, quite a number of advanced economies, most notably in Europe, have deepened their economic integration beyond the standard WTO and IMF norms in liberalisation of the trade account and the capital account. If there were not general recognition in Western Europe that WTO-plus and IMF-plus levels of economic integration would produce large economic benefits, the EU project would not have been realised in just 50 years after so many centuries of strife between distinct nation-states. The establishment of the North American Free Trade Area (NAFTA) in 1994 was an endorsement by the North American economies of Western Europe's judgment about the material benefits of WTO-plus and IMF-plus economic integration.

There is now, however, increasingly widespread dissatisfaction with the trade and financial components of the international economic architecture that have created so much prosperity in so many countries. The growing unhappiness with the financial components has quite disparate origins. First, the present frailties of the US economy and its damaged financial system have spurred renewed concern about the stability of an international financial system that operates largely on a US dollar standard. Zhou Xiaochuan (2009), Governor of the People's Bank of China, has recently revived the suggestion by Robert Triffin that the amount of special drawing rights (SDRs) issued by the IMF be greatly increased so that they can displace the US dollar as the medium of exchange in international transactions.

Another way to displace the US dollar from its central role in international transactions (and hence as a reserve currency) is for East Asia to provide an alternative medium of exchange (and hence an alternative store of value) by creating a common Asian currency. After all, the combined ChinaJapan-South Korean gross domestic product (GDP) will exceed US GDP in 2025, with China's GDP alone exceeding US GDP by 2040. In the opinion of Haruhiko Kuroda, President of the Asian Development Bank (ADB), a common East Asian currency is a realistic objective:

The more we think about a single currency the greater the political factor seems to dominate. Especially in Asia, where political systems vary so much from country to country and political rivalries between countries are still so intense, we tend to be pessimistic about 
a single currency even in the long run...[H]owever, if we look at the younger generations who are free from old nationalistic sentiment, we can be more optimistic. ('The case for Asian monetary union', Wall Street Journal, 1 June 2004)

The second area of unhappiness with the financial component of the international economic architecture is the growing rejection of the 'Washington Consensus' that has undergirded the policy advice of the IMF. The East Asian financial crisis exposed the inadequacy of the Washington Consensus, which downplayed the existence of speculative bubbles and the importance of investments in science to sustain high growth. ${ }^{4}$ The resulting one-size-fits-all approach of the IMF's rescue packages has seriously eroded the trust in the technical competence of the IMF, and this trust has been the basis for the unusual monopoly status that the IMF enjoys as the world's sole monetary body. This is unlike the World Bank, which faces potential scrutiny from the regional development banks such as the $\mathrm{ADB}$, the Inter-American Development Bank, the European Bank for Reconstruction and Development and the African Development Bank.

Dissatisfaction with the WTO-led trade system has also been growing in recent years. The turn against free trade is well illustrated by the surveys in 2003 and 2007 of the public's attitude towards trade, conducted in 30 countries by the Pew Research Center $(2003,2007)$. The decline in support for free trade is most pronounced in the United States. The proportion of US residents who have a positive view of trade in 2007 was only 59 per cent - the lowest satisfaction level in the sample. This was also a dramatic drop from the 78 per cent reported in the 2003 survey.

This rise in discontent with trade is a global phenomenon. Of the 38 countries in the sample, 27 reported a drop in support for free trade, two countries were unchanged in their views and nine countries increased their support. The most alarming sign of a threat to the WTO system is that six of the G7 countries (the United States, France, Germany, Italy, the United Kingdom and Canada) view trade in a more negative light than before. None of the nine countries that have become more ardent supporters of trade is a major trading power at present.

A large part of the unhappiness with the WTO-led trade system has come to rest on the persistent trade account surpluses of China, which reached 11.3 per cent of GDP in 2007. At a US congressional hearing in March 2007, Morris Goldstein (2007) opined that the renminbi was overvalued by 40 per cent against the US dollar and accused China of 
exchange rate manipulation - a charge echoed by Fred Bergsten (2007). On 12 June 2007, Peter Mandelson, the trade commissioner for the European Union, described China's trade policy as 'illogical', 'indefensible' and 'unacceptable' and accused China of doing nothing to rein in rampant counterfeiting ('Surplus fuels EU-China war of words', Financial Times, 13 June 2007). On 14 June 2007, a bill was introduced in the US Senate 'to punish China if it did not change its policy of intervening in currency markets to keep the exchange value of the currency, the yuan, low' ('4 in Senate seek penalty for China', New York Times, 14 June 2007). In the 2007-08 period, the US trade representative launched a record number of WTO suits against China's trade practices. ${ }^{5}$

This chapter will confine itself to the narrow task of analysing the desirability from China's viewpoint of supporting new forms of international monetary-financial cooperation in order to reform the international monetary system in the direction of reducing the global role of the US dollar and to improve the global ability to fight financial market disorders.

\section{Starting on the road to a common Asian currency?}

In retrospect, the East Asian financial crisis of 1997-98 gave a huge boost to the impetus towards Asian economic integration. The yearning for greater economic integration in post-crisis Asia was due as much to the consequences of the typhoon that appeared in the Gulf of Siam on 2 July 1997 as it was to the causes of the financial typhoon and the responses of the international financial institutions, the United States and Western Europe.

East Asians drew two lessons from the East Asian financial crisis. The first lesson is that the Washington Consensus doctrine is blind to the ability of the financial markets to price financial assets incorrectly on a large scale. A better picture of the working of financial markets is that of Paul Volcker (1999), who said:

International financial crises, I might even say domestic financial crises, are built into the human genome. When we map the whole thing, we will find something there called greed and something called fear and something called hubris. That is all you need to produce international financial crises in the future. 
Because the IMF (under the influence of the Washington Consensus) regarded the collapse of output in Asia as the inevitable consequence of an unsustainable economic system that was created by government policies catering to crony capitalism, the initial IMF rescue packages stressed severe monetary-fiscal tightening and a drastic overhaul of the economic system and incentive structure (for example, immediate increases in the capital adequacy ratio and abrupt large-scale closures of financial institutions) to restructure the economy in order to restart growth. This initial misjudgment explains why the IMF kept under-predicting until the end of 1998 the strength of the growth that occurred.

The second important lesson drawn by East Asians is that the only form of reliable help during an economic emergency is self-help. The IMF could not be counted on to always be correct in its diagnosis on its first reading of the situation. Moreover, the United States could not be expected to be always ready to help out countries in desperate straits. In the three-decade-long rule of Indonesian President General Suharto, he had been bailed out several times by the United States and its allies (notably, Australia, Japan, the Netherlands and the international financial institutions), and it was thus quite natural for him to expect some external aid when things started going awry in the last quarter of 1997. Suharto was mistaken. He did not realise that with the end of the Cold War in 1992, he was dispensable to US security and ideological interests just like his fellow general, Joseph Mobuto of Congo-Zaire.

The only countries that were willing to commit immediate large-scale financial assistance to the crashing East Asian economies were neighbouring Japan and Australia. Japan proposed the Asian Monetary Fund (AMF). Japan did not succeed, however, in establishing the AMF. There were three key reasons for the failure of the initiative. First, some important industrialised countries believed in the crony capitalism explanation of the crisis, and concluded that an AMF would merely mean throwing more money to the undeserving, corrupt elite of these countries. Secondly, some other industrialised countries wanted to protect the monopoly position of the IMF so that they could continue to command a disproportionate influence on world affairs. Third, China was not prepared to be rushed by events into supporting a new regional institution without careful consideration of all the implications.

These two lessons propelled the East Asian countries after their recovery to go on a reserves-accumulation spree to insulate themselves from future 
speculative attacks - that is, to be independent of the supervision of the IMF. These lessons also led the Asian countries - the 10 Association of South-East Asian Nations (ASEAN) countries, China, Japan and South Korea, collectively called ASEAN+3 - to start the process of currency and financial cooperation when they met in Chiangmai, Thailand, in 2000. The resulting 'Chiangmai Initiative' had two major components.

The first component was that countries agreed to come to one another's aid if similar speculative attacks were to reoccur. This pooling of reserves to defend the existing values of their exchange rates was enabled by each country entering into a web of bilateral swap arrangements. The second component was the establishment of an Asian Bond Market (ABM) to keep funds within the region. The assumption was that if there was a panic-led capital flight from one Asian country, the existence of the ABM would channel these funds to the other Asian countries. The ABM was a defensive mechanism (just like the antiballistic missile) and it worked by reducing the probability of a collective capital flight from Asia.

At the May 2006 meeting of the ADB in Hyderabad, India, the bank led the calls for the introduction of an Asian currency unit (ACU) to coordinate exchange rate movements within the region. This proposal was similar to the first major step towards currency unification in Europe when the European currency unit (ECU)_-more popularly known as the European currency snake - was introduced in 1976 to coordinate a joint float against the US dollar. Would Asia, in three years after Hyderabad, as Europe did in 1979, form the Asian equivalent of the European monetary system? And would it then grow into an Asian monetary union in another 20 years?

Given the many parallels ${ }^{6}$ between the rapid developments in Asia in the past decade with the movement in Europe from the Treaty of Rome in 1957, which established the European Economic Community, to the Maastricht Treaty in 1993, which formalised the European Union, the sense of history repeating itself is naturally a strong one. Is there an Asian Economic Union (AEU) in the offing? Will it come soon, just like a late industrialiser taking off at explosive speed compared with the first industrialiser?

We know enough from painful experience, however, to be wary of linear thinking; otherwise, there would never be any turning points in history. We do well to remember Karl Marx' words: 'History repeats itself, first as tragedy, second as farce. ${ }^{7}$ 


\section{The economic basis for exchange rate coordination and a common currency}

The basic question is whether the final realised form of the Asian Economic Union (AEU) will be closer to the European Union or to NAFTA. The European Union and NAFTA are similar in that they permit the free movement of goods and capital within their respective groupings. They also, however, differ in many significant aspects. Unlike the European Union, NAFTA allows only limited labour mobility across countries (notably, there are restrictions on labour movements from Mexico to the United States and Canada), it has no plans to coordinate exchange rate policies and it does not envisage an eventual political union.

Even so, recent events do not suggest that the European Union and NAFTA will continue to evolve steadily towards their stated final forms. When the citizens of France and the Netherlands, in 2005, and of Ireland, in 2008, were allowed to express their choice at the voting booth about the desirability of moving on to the next stage of integration, they rejected the motion. It is commonly believed that if the United Kingdom and Italy had conducted referendums on the issue, their citizens would have also rejected continued European integration. During the US primary elections for nomination as the candidate of the Democratic Party, Hillary Clinton and Barack Obama expressed the possibility of renegotiating the terms of NAFTA.

Amid these contrary developments within the European Union and NAFTA in the past few years, more prominent Asian voices have, however, emerged in support of building an AEU. For example, in 2005, Haruhiko Kuroda, the President of the ADB, called for Asia to move 'towards a borderless Asia'; and, in 2008, he reported that despite Asian economic integration being a challenging task, 'Asia is poised to take these steps' (Kuroda 2005, 2008).

So far, no prominent proponent of an AEU has advocated a future political union as a final objective. While political objectives such as the avoidance of armed conflict among traditional competitors might suffice to drive the economic integration agenda, it would be more rational to also explicitly acknowledge the economic costs of these political decisions. To put the issue more fundamentally, is there a case for exchange rate coordination (and, maybe, monetary integration) within an AEU in the absence of political unification? 
In our opinion, we cannot compare the relative merits of an EU-type AEU and an NAFTA-type AEU without stating what the world will look like in the future. Luckily for us, the conventional views of the state of the world in 2025 and 2050 are conveniently contained in a Goldman-Sachs study (O'Neill et al. 2005). Projections have been made for the inflationadjusted GDP in the major countries in the European Union, NAFTA and the AEU for 2025 and 2050 (Table 2.1).

\section{Table 2.1 The world economy in 2005, 2025 and 2050 according to GDP}

\begin{tabular}{|c|c|c|c|}
\hline & United States & Canada & Mexico \\
\hline 2005 & 12.5 & 1.2 & 0.7 \\
\hline 2025 & 19.6 & 1.8 & 2.4 \\
\hline 2050 & 37.7 & 3.0 & 7.8 \\
\hline \multicolumn{4}{|c|}{ Case 2 EU GDP: Fairly equal in size } \\
\hline & France & Germany & United Kingdom \\
\hline 2005 & 2.3 & 3.1 & 2.3 \\
\hline 2025 & 3.2 & 3.9 & 3.3 \\
\hline 2050 & 4.9 & 5.4 & 5.1 \\
\hline \multicolumn{4}{|c|}{ Case 3 Asia GDP: Japan dominates now; China dominates in the future } \\
\hline & China & South Korea & Japan \\
\hline 2005 & 1.9 & 0.8 & 5.3 \\
\hline 2025 & 11.7 & 2.6 & 6.7 \\
\hline 2050 & 48.6 & 3.7 & 8.0 \\
\hline
\end{tabular}

Note: GDP is measured in US\$ trillion in 2005 prices.

Source: O’Neill, J., Wilson, D., Purushothaman, R. and Stupnytska, A. 2005, How solid are the BRICs?, Global Economics Paper, no. 134 (15 December 2005), Goldman Sachs.

Case 1 in Table 2.1 focuses on the three NAFTA countries: the United States, Canada and Mexico. If we select for the normalisation of GDP in each year, the current GDP of the country that had the smallest GDP in 2005, the GDP ratio of the United States-Canada-Mexico in each year would be: 17.9:1.7:1.0 in 2005; 8.2:0.8:1.0 in 2025; and 4.8:0.4:1.0 in 2050.

While the United States will become increasingly large vis-a-vis Canada and decreasingly large vis-a-vis Mexico, the fact is that the United States is the overwhelmingly dominant country in NAFTA at present and will continue to be so in the future. In 2050, the United States will be 12 times larger than Canada and almost five times larger than Mexico. Given this great disparity in economic size, it will always be true that independent economic shocks in Canada and Mexico will have very limited impact on 
the US economy, while a sneeze by the United States could send powerful tremors to the other two NAFTA members. In such an unequal situation, the survival of individual currencies is natural because the giant US economy sees no advantage in allowing its monetary policy to be influenced by the concerns of the smaller economies, and Canada and Mexico could use the exchange rate as an additional instrument to help offset shocks (especially trade shocks) originating from the US economy.

Case 2 in Table 2.1 reports the GDP of the three largest economies in the European Union: Germany, the United Kingdom and France. Again, using the smallest country in 2005 (France in this case) to normalise GDP, we see that the GDP ratio of Germany-the United Kingdom-France will be: 1.3:1.0:1.0 in 2005; 1.2:1.0:1.0 in 2025; and 1.1:1.0:1.0 in 2050.

The GDP ratios reveal clearly that the biggest EU economies are of the same magnitude now and will continue to be so in the future. This means that independent shocks in each country will have sizeable spill-over effects on the others. This high level of economic interdependence among EU members means that the welfare of each member will be increased if national economic policies are coordinated in a manner that reduces negative spill-over effects. One instrument for achieving this welfareenhancing cooperative solution is a common currency.

Furthermore, in the political dimension, the natural compromise solution for a group of equally powerful countries is a common currency rather than the adoption of any particular national currency. The fact that Europe is anxious to undertake political union in order to minimise the possibility of another war between Germany, the United Kingdom and France means that a common currency is a necessary by-product. In 1950, when the French Foreign Minister, Robert Schuman, pushed for the creation of the European Coal and Steel Community - the forefather of the European Union-he explicitly admitted that this was a way to prevent further war between France and Germany. With the steel and coal industries under the control of a supranational organisation, war would have been 'not only unthinkable but materially impossible' (<http://en.wikipedia.org/wiki/European_Coal_and_Steel_Community $>$ ).

Case 3 in Table 2.1 projects that the distribution of GDP of the three major East Asian economies - Japan, China and South Korea-will display drastic changes over time. The GDP ratio of Japan-China-South Korea will be: 6.6:2.4:1.0 in 2005; 2.6:4.5:1.0 in 2025; and 2.2:13.1:1.0 in 2050 . 
Unlike the European Union, an AEU will not be a club of equals at any point in time; and, unlike NAFTA, there is no stable dominant economic giant across time. Japan is the economic giant in 2005, but China will be the economic giant in 2050. If there is a compelling economic argument to form a yen bloc today, the same economic reasoning would dictate that this yen bloc transform itself into a yuan bloc by about 2035 .

Because Chinese policymakers must be well aware of the changing balance in economic power within East Asia in the next three decades, it is hard to see, why China today would want to support the establishment of a regional economic architecture that would establish a yen bloc. Similarly, even if China were to agree to the formation of a yen bloc now, it is hard to see why it would not seek to change the fundamental nature of the regional financial architecture after 2035. It is, in short, politically unrealistic to expect a common currency for East Asia in the foreseeable future.

Moreover, it is also economically undesirable for East Asia to adopt a common currency because there has not been serious consideration of complete integration of national labour markets in the official and academic discussions of an AEU. If economy $\mathrm{A}$ is entering into inflation while economy B is entering into recession, A will want to raise the interest rate while $\mathrm{B}$ will want to lower the interest rate. The uncomfortable reality is that whatever the compromise interest rate policy might be, it will be optimal only if labour from B can move freely and without cost to A. ${ }^{8}$ Without unhindered labour mobility across $\mathrm{A}$ and $\mathrm{B}$ as the adjustment mechanism to a common monetary policy, the benefits of a common currency could be greatly reduced, if not overwhelmed.

Our opinion is that the NAFTA-like disparity in economic power in an AEU at present and in the future and the absence of policyinduced integration of national labour markets mean that the only stable configuration is the survival of individual East Asian currencies with limited coordination among them in normal times. It therefore appears to us that the many present efforts to promote closer exchange rate cooperation will not succeed in the long run. 


\section{China should support the creation of an Asian financial facility as a means of reforming the international financial architecture}

In our opinion, the present deep global financial crisis has given Asia an opportunity to establish a feasible form of Asian financial cooperation as part of its efforts to help reform the international financial architecture. At the G20 summit meetings in Washington, DC, on 15 November 2008 and in London on 2 April 2009, French President, Nicolas Sarkozy, and UK Prime Minister, Gordon Brown, called on the G20 to establish an IMF greatly enhanced in both financial lending power and regulatory supervisory power. We agree that an improved IMF is highly desirable, but a greatly enhanced Asian swap facility - the Asian Financial Fund (AFF) - would be a superior first line of defense against financial contagion in Asia, because Asia collectively now has enough reserves to fend off unwarranted speculative attacks on a subset of its members. It must be emphasised that the core mission of the AFF is to combat financial contagion and not to finance balance-of-payments adjustment caused by economic mismanagement. This present emphasis by the AFF on the former is what distinguishes it from the IMF, which has both functions as its core mission.

An AFF is necessary because it is simply impossible (and certainly inefficient) to increase the size of the IMF enough to enable it to have indepth expertise on most of the countries to be able to respond optimally in a timely manner to each national crisis. Furthermore, the IMF's policies are decided by executive directors who usually take their orders from their national ministries of finance and central banks, and it would be credulous to think that a significant proportion of these national economic agencies have up-to-date understanding of most of the emerging economies. Even if the improved technical competence of the IMF is not doomed to disappoint the emerging economies, they will be disappointed by the long time required for an improved IMF to appear. The negotiations on meaningful IMF reforms will inevitably be cantankerous and hence protracted.

The Sarkozy-Brown proposal for a new Bretton Woods should be recognised to be part of the continuing effort by Old Europe to maintain its disproportionate representation in global governance bodies such as the UN Security Council, the IMF and the World Bank. ${ }^{9}$ The proposal to make the unreformed IMF the super financial policeman of the world is foolish because the concentration of so much power in its hands would 
magnify the impact of any incorrect operational procedure and allow the mistake to remain unchecked for a longer time. If need be, the assignment of global financial regulation to an expanded Bank for International Settlements (BIS) would be a better alternative. The IMF should forgo its dream of jurisdictional expansion and become instead a more specialised agency that undertakes macroeconomic surveillance for the world and balance-of-payments assistance for the emerging economies.

Right now, East Asia has a thin network of swap lines to defend its currencies. It would be desirable to hasten the evolution of the existing swap facility into the AFF by two actions. First, the existing swap facility specifies that a cumulative drawing that exceeds 20 per cent of a country's quota requires the country to accept IMF supervision. This 'flight-tothe-IMF' clause should be removed because painful memories of 1997-98 make it politically suicidal for any East Asian leader to do so.

Second, the Asian swap facility must now establish a surveillance mechanism to pre-qualify its members for emergency loans (Wang and Woo 2004). Without a credible procedure to pre-qualify members, the removal of the 'flight-to-the-IMF' clause will guarantee that the present system of (bilateral and multilateral) swap arrangements will not be sustainable and will not increase to meaningful sums. This is because the members want the pooled funds to be used only to defend an exchange rate against speculative attacks not justified by fundamentals. The members will not support using the pooled reserves to defend an exchange rate that has been rendered overvalued by inflationary domestic policies. Without prequalification of potential borrowers, no member will be willing to risk committing a large part of its reserves to the swap facility.

During the height of the East Asian financial crisis, the United States, Western Europe and China opposed the establishment of an Asian Monetary Fund to help handle the crisis. Why should they now support the setting up of the AFF, which will have some of the same features as the rejected AMF? There are six reasons for a change of mind.

The first reason is that the 2008 global financial crisis has removed all doubt that financial panic and not crony capitalism was the cause of the East Asian financial crisis, and that the IMF's programs made matters worse.

The second reason is that the United States and Western Europe cannot really stop such a move anyway because: 1) East Asian economies now 
have the requisite amount of foreign exchange reserves to undertake selfinsurance against speculative attacks on a subset of their members; and 2) China has now changed its mind about the desirability of a regional financial institution.

The third reason is that there is now realisation by the United States that, when dealing with Asia, it should rely less on the hard power of a formal dominant role in global leadership and more on the soft power of US example - such as helping Asia do what is best for Asia (which is an excellent start for the United States' re-engagement with Asia). The United States' support for the AFF is a much-needed change towards an inclusive US approach that is diversified in modality to handle each specific multilateral issue. Such a change in modality by the United States would be a realistic response to the shift towards Asia as the centre of gravity for the world economy.

The fourth reason is that with the end of the Cold War, the international agenda of the United States is no longer so similar to that of the Western European countries. This is why when President Sarkozy pressed former US President George W. Bush in October 2008 to convene a G7 summit to deal with the global financial crisis, Bush chose to convene a G20 summit instead. The international economic agendas of the United States and some of the major developing countries now share many more common elements that are at odds with the position of the European Union-for example, on agricultural subsidies.

The fifth reason is that the United States and the rest of the interested world will be members of the AFF just as they are now influential members of the ADB. The creation of the AFF would not mean the disappearance of their policy engagement with Asia. Furthermore, just as we have the system of the World Bank and several regional development banks (such as the Inter-American Development Bank and the African Development Bank), it is also natural and desirable to have regional financial institutions in addition to the IMF. The IMF by no means becomes obsolete with the establishment of the regional financial institutions. The IMF can play a very helpful role in speeding up the institutional maturity of these regional financial institutions and in keeping up the competition of ideas.

The sixth reason is that the AFF could expand over time to be an Asia-Pacific Economic Cooperation (APEC)-level institution and be a good partner to the IMF because 'two heads are better than one' in analysing unexpected, quickly evolving crises and preventing their contagion. In 
short, the better way to improve the supply of global public goods is not to simply increase the size of the existing providers but to increase the number of providers while seeking to improve the performance of existing ones.

Of course, over time, depending on the progress in reforming the operations and the governance of the IMF, and the new needs created by greater Asian economic integration, the Asian community might empower the AFF to also extend adjustment loans with conditionality to countries that needed balance-of-payments assistance because of past economic mismanagement. It is important to note that pooling national foreign exchange reserve funds and using them to enhance regional welfare is independent of whether the AFF will promote exchange rate coordination or not. One activity does not imply the other.

\section{Summing up}

Our formulation of an Asian Financial Fund is operationally the establishment of a large Asian swap facility that has its own surveillance mechanism to pre-qualify members for emergency loans. The primary mission of the AFF is to calm panic in the foreign exchange markets and not to defend currencies that have been rendered overvalued by domestic inflationary policies. The AFF's goal is to attenuate the cost of bad luck and not the cost of bad policies.

Given the large size of East Asian foreign reserves, the AFF should take on the additional task of designing a pooling scheme where part of the East Asian reserves could be safely used to finance sound infrastructure projects in the poorest Asian countries. This outcome would be superior to the present practice of putting almost all of the East Asian foreign reserves into the assets of $\mathrm{G} 7$ economies.

It is important that the AFF does not suffer from the institutional inertia that is characteristic of the current global organisations such as the United Nations, the World Bank and the IMF. The leadership structure of the AFF should be designed to avoid simply locking in the balance of economic power that exists at the time of its founding-unlike the unchanging composition of the permanent members of the UN Security Council, the head of the World Bank always being a US appointee and the head of the IMF always being a European. If the AFF can adopt a self-updating type of leadership structure, its first contribution to the world (as well as 
to the East Asian region) will be the provision of an example to inspire positive developments in the reform of the leadership structure in global organisations.

\section{References}

Bergsten, C. F. 2007, The dollar and the renminbi, Statement before the Hearing on US Economic Relations with China: Strategies and options on exchange rates and market access, 23 May 2007, Subcommittee on Security and International Trade and Finance, Committee on Banking, Housing and Urban Affairs, US Senate, Washington, DC.

Goldstein, M. 2007, Assessing progress on China's exchange rate policies, Testimony before the Hearing on Risks and Reform: The role of currency in the US-China relationship, 28 March 2007, Committee on Finance, US Senate, Washington, DC.

Kuroda, H. 2005, Towards a borderless Asia: a perspective on Asian economic integration, Speech, 10 December 2005, Asian Development Bank, Manila, <http://www.adb.org/Documents/Speeches/2005/ms2005088.asp>

- 2008, The challenges of economic integration, Speech, 12 September 2008, Asian Development Bank, Manila, <http://www.adb.org/Documents/Speeches/2008/ms2008070.asp>

Marx, K. 1852, The Eighteenth Brumaire of Louis Bonaparte, Marxists web site <http://www.marxists.org/archive/marx/works/1852/18th-brumaire/>

Mundell, R. A. 1961, 'A theory of optimum currency areas', American Economic Review, vol. 51, pp. 657-65.

O'Neill, J., Wilson, D., Purushothaman, R. and Stupnytska, A. 2005, How solid are the BRICs?, Global Economics Paper, no. 134 (15 December 2005), Goldman Sachs.

Pew Research Center 2003, 'Views of a changing world', Pew Global Attitudes Survey, Pew Research Center, Washington, DC, <http://pewglobal.org/reports/pdf/185.pdf>

2007, 'World publics welcome global trade-but not immigration', Pew Global Attitudes Survey, Pew Research Center, Washington, DC, $<$ http://pewglobal.org/reports/pdf/258.pdf> 
Volcker, P. 1999, 'A perspective on financial crises', in J. Sneddon Little and G. Olivei (eds), Rethinking the International Monetary System, Federal Reserve Bank of Boston, Conference Series, no. 43, June 1999.

Wang, Y. and Woo, W. T. 2004, 'A timely information exchange mechanism, an effective surveillance system, and an improved financial architecture for East Asia', in Asian Development Bank, Monetary and Financial Integration in East Asia: The way forward. Volume 2, Palgrave Macmillan, pp. $425-58$.

Woo, W. T. 2004, 'Serious inadequacies of the Washington Consensus: misunderstanding the poor by the brightest', in J. Joost Teunissen and A. Akkerman (eds), Diversity in Development: Reconsidering the Washington Consensus, December 2004, Forum on Debt and Development, The Hague, Netherlands.

Zhou, X. 2009, Reform the International Monetary System, People's Bank of China, Beijing.

\section{Endnotes}

1. This chapter is part of the first phase of my project on China's New International Economic Responsibilities.

2. In the aftermath of the 1997-98 capital account crises in East Asia, however, the IMF has been more muted and circumspect in its advocacy of capital account opening. Another international organisation that champions capital account liberalisation is the Organisation for Economic Cooperation and Development (OECD), which makes an open capital account a prerequisite for membership.

3. The euro and the yen are also major currencies but they are seldom used in transactions that do not involve agents in the Euro Zone countries and Japan.

4. See Woo (2004) for a review and critique of the Washington Consensus doctrine.

5. In the February-April 2007 period, the United States filed a WTO suit against Chinese subsidies to exports, Chinese import restrictions on copyright-intensive imports and China's weak protection of copyrights. On 19 December 2008, the United States filed a WTO suit against China's programs to establish global brands for its products because they were seen as export subsidies.

6. The Chiangmai Initiative turned out to be only the first part of a more comprehensive program of regional economic integration. In November 2001, China and ASEAN agreed to start negotiations for an ASEAN+1 free trade area (FTA) that would be achieved in 2010. By November 2002, China and ASEAN had made enough progress to sign the framework agreement for the ASEAN+1 FTA. This fast pace of economic embrace between ASEAN and China had the synergistic effect of accelerating what had been a leisurely paced process of incremental economic integration within ASEAN, and of energising Japan into active FTA negotiations with ASEAN. The ambition of Asian economic integration, or at least its rhetoric, has continued to broaden. The annual ASEAN+3 conference in 2005 was 
supplemented by the East Asian Summit (effectively an ASEAN+6 conference) to include Australia, India and New Zealand; and the host of the 2005 conference, Prime Minister Abdullah Badawi of Malaysia, expounded on his vision of an Asian community.

7. This is the common paraphrase of the opening sentences in Marx (1852).

8. This is the fundamental insight of Mundell (1961).

9. The veracity of this statement is striking in that the G20 summit in November 2008 turned out to be a G22 summit because some of the European members pressed successfully for the inclusion of the Netherlands and Spain. 